\title{
Study of Seasonal Variation of Physicochemical Parameters of River Kaduna, Kaduna State Nigeria
}

\author{
${ }^{1}$ Fadimatu Muhammad, ${ }^{2}$ Sa'idu Abdulkadir and ${ }^{3}$ JehuAuta, \\ ${ }^{1}$ Department of Biological Sciences, Abubakar Tafawa Balewa University Bauchi \\ Bauchi- Nigeria \\ ${ }^{2}$ Department of Biological Sciences, Kaduna State University, Kaduna - Nigeria \\ ${ }^{3}$ Department of Biological Sciences, Ahmadu Bello University Zaria - Nigeria
}

\begin{abstract}
Background: The physiochemical parameters of a river tell much about its quality and suitability for both humans and the survival of the living biota within it. The discharge of untreated wastewater into the surface water bodies such as streams and rivers results in the pollution of such water environments. We aimed to determine the physicochemical parameters and also determine the seasonal variation of the physicochemical parameters river Kaduna.

Methodology: The research was carried out within four areas in Kaduna North, Kaduna state, Nigeria. Selected sampling sites include; Gamji Park, Kabala Costain, Malali and Unguwar Rimi. Monthly sampling of the four sites was carried out from each sampling site for a period of eight months covering both the dry and the rainy season between 6:00 am and 8:00 am every sampling day. The following parameters were determined using standard laboratory techniques; temperature, $\mathrm{pH}$, turbidity, total dissolved solids, electrical conductivity, dissolved oxygen, biological oxygen demand, water hardness, nitrate-nitrogen and phosphate-phosphorus. Data was analyzed using simple descriptive statistics to calculate the mean, standard error (SE) and standard deviation of the parameters.
\end{abstract}

Results: The mean water temperature was $23.6 \pm 0.90 \mathrm{C}$ with a standard deviation of 2.5 , the highest temperature $(25.7 \pm 0.60 \mathrm{C})$ was recorded in the wet season. Mean $\mathrm{pH}$ was $7.9 \pm 0.1$ with a standard deviation of 0.4, the wet and the dry season had the same mean values of $7.9 \pm 0.1$. The mean turbidity was $60.3 \pm 4.6$ with a standard deviation of 12.8 , the wet season had the highest value (72.5 $\pm 2.4 \mathrm{NTU}$ ). Mean TDS was $72.1 \pm 13.9$ with a standard deviation of 38.9 and the highest TDS value of $92.7 \pm 22.9 \mathrm{mg} / \mathrm{L}$ was recorded in the dry season. The mean values of electrical conductivity, dissolved oxygen and biological oxygen demand was $135 \pm 27.7 \mu \mathrm{s} / \mathrm{cm}, 2.6 \pm 0.1 \mathrm{mg} / \mathrm{L}$ and $1.3 \pm 0.1 \mathrm{mg} / \mathrm{L}$ respectively whereas water hardness, nitrate-nitrogen and phosphate-phosphorus had means of $143.5 \pm 13.0 \mathrm{mg}(\mathrm{CaCO} \mathrm{L}-1,0.3 \pm 0.0 \mathrm{mg} / \mathrm{L}$ and $0.1 \pm 0.1 \mathrm{mg} / \mathrm{L}$ respectively.

Conclusion: physicochemical parameters were determined to be within the permissible level and wide seasonal variations were seen among some parameters.

Keywords: Physicochemical Parameters, Dissolved Oxygen, pH, Turbidity, TDS.

\section{INTRODUCTION}

The physiochemical parameters of a river tell much about its quality and suitability for both humans and survival of the living biota within it [1]. River ecosystem is one of the natural resources which come in to the service of mankind in many parts of the world [2]. Urbanization, expansion of irrigation and increasing trend of industrialization has contributed towards the demand for water. The discharge of untreated waste water in to the surface water bodies such as streams and rivers results in the pollution of such water environments. This pollution of surface water bodies resulting from anthropogenic activities is a growing concern worldwide [3]. The water we drink is an essential ingredient for our well being and a healthy life but unfortunately polluted water and air are common throughout the world [4]. Diseases facing mankind today occur due to prolonged exposure to polluted water. River Kaduna serves as a center for re-creation, fishing and irrigation purposes, and also as a sink for disposal municipal and industrial wastes. Urbanization and human activities along the river area may play a great role in polluting the water in river Kaduna. Industrial effluent, domestic effluent and agricultural run-off may cause serious effects to the water quality. Therefore, this research aimed to determine the physicochemical parameters of the river and also to determine seasonal variation of the physicochemical parameters of the river. 


\section{METHODOLOGY}

The research was carried out within four areas in Kaduna North, Kaduna state, Nigeria. Kaduna metropolis is located within the guinea savannah with co-ordinates latitude $10^{0} 31^{\prime} 23^{\circ} \mathrm{N}$, Longitude $7^{0} 26^{\prime} 25^{\circ} \mathrm{E}$. Selected sampling sites include; Gamji Park, where river Kaduna passes through the Park. Here, pollutants in to the river are generated from Kaduna State University (KASU), Police College and nearby settlements; Kabala costain, where river Kaduna passes. Here, the pollutants are high domestic discharge and light agricultural discharges; Malali water treatment works. This served as a control for the study; Unguwan rimi. Here, a lot of agricultural (farming and fishing activities) are taking place. Monthly sampling of the four sites was carried out from each sampling site for a period of eight months covering both the dry and the rainy season between 6:00am and 8:00am every sampling day.

Temperature of water was determined in the field by using Mercury in glass thermometer. The thermometer was dipped into the water and was allowed to equilibrate for three minutes. Readings were taken and recorded in the nearest degree Celcius.

$\mathrm{pH}$ of the water samples was determined by placing a callibrated pH probe (HANNA HI 96107) in to the samples and was allowed to equilibrate for three minutes. $\mathrm{pH}$ readings were taken and recorded.

Electrical conductivity was determined by dipping the conductivity probe in to the samples and allowed to equilibrate for three minutes. The electrical conductance was taken twice and an average was calculated and recorded in microsiemens $/ \mathrm{cm}(\mu \mathrm{s} / \mathrm{cm})$.

Total dissolved solids of the water was determined by dipping probe in to the samples and allowed to equilibrate for about three minutes. Readings were taken, the average was calculated and recorded in parts per million (ppm) and converted to milligram per litre $(\mathrm{mg} / \mathrm{L})$.

Dissolved oxygen was determined by Azide modification of Winkler method. Water sample was poured in to a 300mL BOD

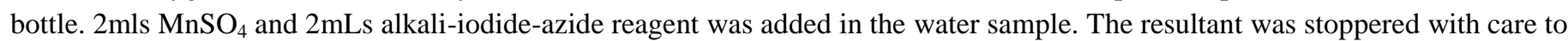
exude air bubbles and mixed gently by inverting the bottle a number of times until a clear supernatant was obtained. The resultant samples were allowed to settle for 2 minutes and $2 \mathrm{mLs}$ concentrated $\mathrm{H}_{2} \mathrm{SO}_{4}$ was added by allowing the acid run down the neck of the bottle. The resultant sample was stoppered again and mixed by gentle inversion until dissolution was complete. $100 \mathrm{mLs}$ of the prepared solution was transferred in to a conical flask and $1 \mathrm{~mL}$ of freshly prepared starch solution was added, making the colour blue. The sample solution was titrated with $0.0125 \mathrm{~N}$ of $\mathrm{Na}_{2} \mathrm{~S}_{2} \mathrm{O}_{3} \cdot 5 \mathrm{H}_{2} \mathrm{O}$ solution to a pale yellow colour. Titration was continued until the blue colour disappeared. Dissolved oxygen percentage saturation was calculated as:DO\% saturation $=(\mathrm{DO} / \mathrm{Saturation}$ level) x 100

Biological Oxygen demand was determined by pouring 300mL of water samplein to a 300mL standard BOD bottle and covered carefully to exude air bubbles. The bottle was then kept in an incubator for five days. $2 \mathrm{mLs}$ of Manganese Sulphate solution was added followed by addition of $2 \mathrm{mLs}$ of alkali-iodide-azide reagent in the 5-days incubated water samples. The resultant samples bottle was stopperred to exude air bubbles and mix thoroughly by inverting the bottle several times. The resultant samples were allowed to settle leaving clear supernatant. $2 \mathrm{mLs}$ of conc. $\mathrm{H}_{2} \mathrm{SO}_{4}$ was added to the resultant samples. The bottle was stoppered again and mixed with gentle inversion. $100 \mathrm{mLs}$ of the prepared solution was transferred in to a conical flask and $2 \mathrm{mLs}$ of freshly prepared starch indicator was added. The solution was titrated with $0.0125 \mathrm{~N}$ of sodium thiosulphate solution until the disappearance of the blue colour.BOD was then calculated using the formula:(BOD) $)_{5}$ in $\mathrm{mg} / \mathrm{L}=\mathrm{DO}_{1}-\mathrm{DO}_{5}$

Total hardness was determined by Ethyl Diamine Tetra Acetic Acid (EDTA) titration method where $2 \mathrm{mLs}$ of water samples collected was transferred in to a conical flask. This was diluted to $500 \mathrm{mLs}$ with distilled water. $2 \mathrm{mLs}$ of hardness buffer solution of $\mathrm{pH} 10.4$ was added, followed by addition $0.1 \mathrm{~g}$ of Errochrome black $\mathrm{T}$ dye. The resultant solution was titrated with EDTA titrant $(0.01 \mathrm{M})$ until there was a pale yellow colour.Total hardness was calculated to be;

Total hardness in $\mathrm{CaCO}_{3} / \mathrm{L}=\mathrm{ml}$ of titrant $\mathrm{x} 40$

Nitrate / Nitrogen was determined using the Phenoldisulphonic acid method where $100 \mathrm{mLs}$ of the sample was evaporated to dryness using a clean dry metallic crucible. The residue was kept in an oven set at $100^{\circ} \mathrm{C}$ till dryness. 2 mls of Phenoldisulphonic acid was added to the residue and the resultant solution was swirled uniformly. The swirled sample was left to stand for 10 minutes, before addition of $10 \mathrm{mls}$ distilled water. $5 \mathrm{mls}$ of concentrated $\mathrm{NH}_{3}$ solution was added to the solution and was allowed to cool. The sample absorbance was read in a Hach spectrophotometer at 430nm wavelength where colour change was observed. The nitrate / nitrogen concentration was determined from a calibration curve. Nitrate / nitrogen was measured in mg/L.

Phosphate / Phosphoruswas determined by pouring $100 \mathrm{mLs}$ of water sample in to a conical flask, $1 \mathrm{~mL}$ of ammonium molybdate reagent was added to make up to $50 \mathrm{~mL}$ mark. The resultant was allowed to stand for 10 minutes and change in colour was 
observed. Absorbance was determined from the resultant with the use of Hach spectrophotometer at 600nm wavelength. The phosphate concentration was determined from a calibration curve. The unit of measurement was in mg/L. mg $\mathrm{PO}_{4} / \mathrm{L}=\mathrm{mg} \mathrm{PO}_{4}$ in $50 \mathrm{~mL}$ volume flask $x 1000 \mathrm{~mL}$ of sample used. The generated data was analysed using simple descriptive statistics to calculate the mean, standard error (SE) and standard deviation of the parameters.

\section{RESULTS}

The results obtained from this study showed variation in water physicochemical parameters. The statistical summary of all the physico-chemical parameters are presented in table 1 below.

Table 1: Summary Statistics of Physicochemical Parameters of River Kaduna

\begin{tabular}{llllll}
\hline Parameters & Units & Mean & SD & Minimum & Maximum \\
\hline Water Temperature & ${ }^{0} \mathrm{C}$ & $23.6 \pm 0.9$ & 2.5 & 20.3 & 26.9 \\
$\mathrm{pH}$ & & $7.9 \pm 0.1$ & 0.4 & 7.1 & 8.5 \\
Turbidity & $\mathrm{NTU}$ & $60.3 \pm 4.6$ & 12.8 & 44.8 & 78.3 \\
$\mathrm{TDS}$ & $\mathrm{Mg} / \mathrm{L}$ & $72.1 \pm 13.9$ & 38.9 & 42.1 & 140.1 \\
$\mathrm{EC}$ & $\mu \mathrm{s} / \mathrm{cm}$ & $135 \pm 27.7$ & 77.5 & 79.2 & 275.0 \\
$\mathrm{DO}$ & $\mathrm{Mg} / \mathrm{L}$ & $2.6 \pm 0.1$ & 0.3 & 2.2 & 2.9 \\
$\mathrm{BOD}$ & $\mathrm{Mg} / \mathrm{L}$ & $1.3 \pm 0.1$ & 0.2 & 1.1 & 1.7 \\
$\mathrm{Hardness}$ & $\mathrm{Mg}(\mathrm{CaCO} 3) / \mathrm{L}$ & $143.5 \pm 13.0$ & 36.4 & 116.7 & 232.0 \\
$\mathrm{NO}_{3}-\mathrm{N}$ & $\mathrm{Mg} / \mathrm{L}$ & $0.3 \pm 0.0$ & 0.1 & 0.1 & 0.3 \\
$\mathrm{PO}_{3}-\mathrm{P}$ & $\mathrm{Mg} / \mathrm{L}$ & $0.1 \pm 0.1$ & 0.3 & 0.1 & 0.2 \\
\hline
\end{tabular}

Key: Temperature (Temp), Niphelometric Turbidity Unit (NTU), Dissolved Oxygen (DO), Biological Oxygen Demand (BOD), Electrical Conductivity (EC), Total Dissolved Solids (TDS), Phosphate-Phosphorus $\left(\mathrm{PO}_{4}-\mathrm{P}\right)$ and Nitrate-Nitrogen $\left(\mathrm{NO}_{3}-\mathrm{N}\right)$.

The physic-chemical parameters of river Kaduna was found to vary between the wet and dry seasons as shown in table 2 below.

Table 2: Seasonal Variations of the Physicochemical Parameters in River Kaduna

\begin{tabular}{lll}
\hline Parameters & Dry Season & Wet Season \\
\hline Temperature & $21.4 \pm 0.8$ & $25.7 \pm 0.6$ \\
$\mathrm{pH}$ & $7.9 \pm 0.1$ & $7.9 \pm 0.1$ \\
Turbidity & $48.1 \pm 1.2$ & $72.5 \pm 2.4$ \\
TDS & $92.7 \pm 22.9$ & $51.5 \pm 4.1$ \\
EC & $180.5 \pm 43.9$ & $89.6 \pm 6.9$ \\
DO & $2.6 \pm 0.2$ & $2.6 \pm 0.1$ \\
BOD & $1.4 \pm 0.1$ & $1.2 \pm 0.1$ \\
Water hardness & $161.1 \pm 22.4$ & $125.9 \pm 2.5$ \\
Nitrate-Nitrogen & $0.2 \pm 0.0$ & $0.3 \pm 0.0$ \\
Phosphate-Phosphorus & $1.1 \pm 0.0$ & $0.1 \pm 0.0$ \\
\hline
\end{tabular}

Physic-chemical parameters of river Kaduna was also found to vary between the sampling stations as shown in table 3 below.

Table 3:Mean Values of the Physicochemical Parameters at the four Sampling Stations in River Kaduna

\begin{tabular}{|c|c|c|c|c|c|c|c|c|c|c|}
\hline Stations & $\begin{array}{l}\text { Water } \\
\text { Temp } \\
\left({ }^{0} \mathrm{C}\right)\end{array}$ & $\mathrm{pH}$ & $\begin{array}{l}\text { Turbidity } \\
\text { (NTU) }\end{array}$ & $\begin{array}{l}\text { TDS } \\
(\mathrm{Mg} / \mathrm{L})\end{array}$ & $\begin{array}{l}\mathrm{EC} \\
(\mu \mathrm{s} / \mathrm{cm})\end{array}$ & $\begin{array}{l}\mathrm{DO} \\
(\mathrm{Mg} / \mathrm{L})\end{array}$ & $\begin{array}{l}\text { BOD } \\
(\mathrm{Mg} / \mathrm{L})\end{array}$ & $\begin{array}{l}\text { Water } \\
\text { Hardness } \\
\left(\mathrm{Mg}\left(\mathrm{CaCO}_{3}\right) / \mathrm{L}\right.\end{array}$ & $\begin{array}{l}\text { Nitrate- } \\
\text { Nitrogen } \\
(\mathrm{Mg} / \mathrm{L})\end{array}$ & $\begin{array}{l}\text { Phosphate- } \\
\text { Phosphorus } \\
(\mathrm{Mg} / \mathrm{L})\end{array}$ \\
\hline 1 & $23.14^{\mathrm{b}}$ & $7.95^{\mathrm{aa}}$ & $60.11^{\mathrm{aa}}$ & $99.79^{\mathrm{a}}$ & $187.17^{\mathrm{a}}$ & $2.56^{\mathrm{bb}}$ & $1.24^{\mathrm{b}}$ & $157.83^{\text {aa }}$ & $0.25^{\mathrm{aa}}$ & $0.07^{\mathrm{aa}}$ \\
\hline 2 & $23.67^{\mathrm{a}}$ & $8.06^{\mathrm{a}}$ & $58.03^{\mathrm{a}}$ & $67.79^{\mathrm{bb}}$ & $128.13^{\mathrm{bb}}$ & $2.77^{\mathrm{a}}$ & $1.44^{\mathrm{a}}$ & $143.50^{\mathrm{ba}}$ & $0.25^{\mathrm{aa}}$ & $0.08^{\mathrm{aa}}$ \\
\hline 3 & $23.97^{\text {aa }}$ & $8.02^{\text {aa }}$ & $60.44^{\mathrm{aa}}$ & $64.67^{\mathrm{bc}}$ & $117.88^{\mathrm{bb}}$ & $2.45^{\mathrm{b}}$ & $1.27^{\mathrm{bb}}$ & $126.83^{b}$ & $0.24^{\text {aa }}$ & $0.06^{\mathrm{a}}$ \\
\hline 4 & $23.95^{\mathrm{aa}}$ & $7.50^{\mathrm{b}}$ & $62.65^{\mathrm{aa}}$ & $55.96^{\mathrm{c}}$ & $107.50^{\mathrm{b}}$ & $2.46^{\mathrm{bb}}$ & $1.26^{\mathrm{bb}}$ & $145.0^{\mathrm{ab}}$ & $0.23^{\mathrm{a}}$ & $0.08^{\mathrm{aa}}$ \\
\hline
\end{tabular}

Means with different letters in each column are significantly different $(\mathrm{P}<0.05), \mathrm{a}>\mathrm{b}>\mathrm{c}$

There was decrease in temperature from December to February and then it increases from the months of May to August. The highest temperature of $27^{\circ} \mathrm{C}$ was recorded during the rainy season in August at stations 2 and 3 while the lowest temperature of $20^{\circ} \mathrm{C}$ was recorded during the dry season in December, January and February at all the four stations. The highest pH of 8.8 was 
recorded in the rainy season in August at station 3 while the lowest $\mathrm{pH}$ of 6.7 was recorded during the rainy season at station 4 in the month of May. The highest value of turbidity was recorded in the month of May at station 4 while the lowest was recorded in the dry season in the month of February at station 2. There was an observed increase in values of TDS from February to March and a decrease from July to August. The highest value was recorded during the dry season in March at station 1 while the lowest value was recorded during the wet season in August at station 2. The highest value of $275.0 \mu \mathrm{s} / \mathrm{cm}$ was recorded in March at station 1 while lowest value of $63.3 \mu \mathrm{s} / \mathrm{cm}$ was recorded in August at station 2 . The highest value of $3.2 \mathrm{mg} / \mathrm{L}$ was recorded in January at station 2 while the lowest value of $1.9 \mathrm{mg} / \mathrm{L}$ was recorded in February at station 4 . The highest value of $2.1 \mathrm{mg} / \mathrm{L}$ was recorded in the months of December and January at station 2 while the lowest value of $1.0 \mathrm{mg} / \mathrm{L}$ was recorded in the months of March and May at stations 1, 3 and 4. The highest value of $293\left(\mathrm{mg}\left(\mathrm{CaCO}_{3} \mathrm{~L}^{-1}\right)\right.$ was recorded in December at station 3 while the lowest value of $106\left(\mathrm{mg}\left(\mathrm{CaCO}_{3} \mathrm{~L}^{-1}\right)\right.$ was recorded in January at station 3 . The highest value of Nitrate-nitrogen of $0.4 \mathrm{mg} / \mathrm{L}$ was recorded in March at station 1 while the lowest value of $0.1 \mathrm{mg} / \mathrm{L}$ was recorded in December and January at all the four stations. The highest value of phosphate-phosphorus of $0.2 \mathrm{mg} / \mathrm{L}$ was recorded in July at station 2 while the lowest value of $0.01 \mathrm{mg} / \mathrm{L}$ was recorded from December to March in the dry season at almost all the four stations.

\section{DISCUSSION}

The quality of water has tremendous impact on the standard and well-being of aquatic organisms. Sigh et al [5] reported that the level of water quality is governed by physicochemical and biological parameters. Ubwa et al [6] documented that temperature influences stability of dissolved oxygen in the water body, hence affects the survival of aquatic organisms. The water temperature of river Kaduna fluctuates with months, which was between $20.3^{\circ} \mathrm{C}$ to $26.9^{0} \mathrm{C}$ in all the four sampling stations. This falls within the acceptable temperature range $\left(16^{\circ} \mathrm{C}-27^{\circ} \mathrm{C}\right)$, suggested by (FEPA, 1983) for biota survival in aquatic habitats. Temperature in water bodies changes daily, monthly, seasonally and even annually, due to changes in surface water temperature and activities around the water body. The lowest temperature recorded in this study was in the dry season, which is similar with the observation of Ibrahim [7] which reported low water temperature during the dry season as a result of seasonal changes in air temperature associated with the cold dry North-East winds. This observation is also similar with the findings of Dadi-Mamud et al [8] and Abubakar [9]. The water $\mathrm{pH}$ during the 8 months study was within the range of $\mathrm{pH} 7.1-8.5$, that is suitable for the survival of aquatic organisms. The pH obtained, was also within the Nigerian standard for drinking water quality safety range of (6.5-8.5) [10] and World Health Organisation standards [11]. The pH obtained is similar with the findings of Edward and Ugwumba [12] where they reported that the reservoir water was alkaline in nature with the pH ranging between 7.4-8.9 in Egbe reservoir, Ekiti state, Nigeria. The $\mathrm{pH}$ values fluctuated from month to month with a fixed band of 7-8. There was no pattern of $\mathrm{pH}$ variation between the four locations. This was similar with the work of Terrumun and Oliver [3]. High values of pH were observed in the months of January, March, July and August which could be as a result of increase in algae populations by their photosynthetic activity.

The turbidity values obtained for all the four locations were within the standard limits of 100-125 NTU [13]. The turbidity values were higher during the rainy season which could be due to the presence of flood water, surface run-offs and settling effects of suspended materials. Turbidity of water is also affected by the amount of suspended solids in it and it reduces the light penetrating depth hence, reduces the growth of plants and disqualified the water for domestic use in the community. Low value of turbidity observed during the dry season may be attributed to low water level in the river due to low flow of drainage water in to the river. Total dissolved solids recorded during the study, falls within the range of $42.1 \mathrm{mg} / \mathrm{L}-140.1 \mathrm{mg} / \mathrm{L}$. The dry season, showed significantly higher TDS than wet season. Higher values of TDS during the dry season could be due to decaying of vegetation, high rate of evaporation caused by increase in air temperature and winds during the dry season. High values of TDS could also be due to domestic waste dumps and industrial discharges in to the river which could alter the balance and composition of water body. Similar observation was made by Babatunde and Hassan [14] where they reported increase in the values of TDS at site 2 from January to March due to increase in number of dumping sites along Adeyemo Street, Kaduna. However, during the rainy season the amount of TDS was low which may be due to dilutional effect of water. The electrical conductivity during the study period were within the range of $79.2 \mu \mathrm{s} / \mathrm{cm}-275 \mu \mathrm{s} / \mathrm{cm}$. The highest value was recorded in the dry season while the lowest value was recorded in the wet season. The high dry season values may be due to the reduction in the water level and increase in nutrients due to run-off of inorganic fertilizer from nearby farm lands. Habibat [15] reported increase in electrical conductivity in Tatsarwaki stream due to agricultural run-off, domestic waste and other human activities in and around the water body. Decrease in EC during the rainy season might be due to dilution by rain water.

The mean range of DO during the 8 months study was $2.2-2.9 \mathrm{mg} / \mathrm{L}$, although the highest DO value was $3.5 \mathrm{mg} / \mathrm{L}$ at station 2 in December which was lower than WHO permissible limit of 4mg/L [11] and FEPA standards (6.0mg/L) [16]. Low DO affects aquatic life, stresses fishes and may result in anaerobic conditions that could cause bad odour [6]. Low DO concentrations in water bodies can be caused by decomposing organic matter, dissolved gases, industrial waste, mineral waste and agricultural run-off [17]. This observation was also made by Babatunde and Hassan [14] with low values of DO observed which indicated high level 
of polluted water probably as a result of various dumping sites along Adeyemo stream Kaduna, Kaduna state, Nigeria. Water with low DO from $0.2-0.5 \mathrm{mg} / \mathrm{L}$ are considered hypoxic while less than $0.2 \mathrm{mg} / \mathrm{L}$ are considered anoxic. Biological oxygen demand mean range recorded in this study were between $1.1-1.7 \mathrm{mg} / \mathrm{L}$ which were less than European Union (EU) permissible limit (3.0 - 6.0mg/L), FEPA (1991) limit (10mg/L) and Universal Water Index of (3.0mg/L) for the protection of fishes, aquatic life and for domestic water supply $[18,19]$. Higher BOD indicates poor water quality while lower BOD indicates low levels of organic waste. Water hardness mean range recorded during the study was between $116.7\left(\mathrm{mg} / \mathrm{L}\left(\mathrm{CaCO}_{3}\right)-232.0(\mathrm{mg} / \mathrm{L}(\mathrm{CaCO})\right.$. Water hardness values at station 1 in the months of December and January, stations 2 and 4 in the month of December were above the permissible limits $\left(20-200\left(\mathrm{mg} / \mathrm{L}\left(\mathrm{CaCO}_{3}\right)\right)[13]\right.$. The highest peak of water hardness recorded in the month of December at stations 1,2 and 4 could be as a result of low water levels and higher concentration of nutrients. Water hardness was reported to be higher during the dry season and lower in the rainy season attributed to low water levels [7].

Nitrate - Nitrogen during this study was found to be between $0.1 \mathrm{mg} / \mathrm{L}-0.3 \mathrm{mg} / \mathrm{L}$. The mean values for nitrate - nitrogen were found to be lower than the water quality standard for aquatic life of WHO standards (10mg/L) [11]. Low concentrations of nutrients generally have significant implications for nutrients dynamics and phytoplankton composition. Low concentration of nitrate - nitrogen could be attributed to decrease in the irrigation practices from leaching of fertilizers from farms, sewage dumps, domestic waste and other organic wastes in to the sampling stations of river Kaduna. The present study is in agreement with the work of Olele and Ekelemu [20], Babatunde and Hassan [14] where they recorded low value of nitrate - nitrogen in the course of their study. The low value of nitrate - nitrogen recorded in their studies was attributed to dumping of refuse, leaching of fertilizers and other organic wastes in to the water bodies. In this study, phosphate - phosphorus has the lowest mean range of $0.1-0.2$ $\mathrm{mg} / \mathrm{L}$. This is lower than the WHO standard limits of $5 \mathrm{mg} / \mathrm{L} \mathrm{[11].} \mathrm{Increase} \mathrm{in} \mathrm{phosphate} \mathrm{levels} \mathrm{could} \mathrm{lead} \mathrm{to} \mathrm{eutrofication} \mathrm{which}$ can be caused by sources such as phosphorus-rich bedrock, reduced water volume, industrial effluents and intensive agricultural activities in form of use of fertilizers and pesticides around the river [6]. The low levels of phosphates and nitrates recorded in the study may have contributed to the reduced abundance in phytoplankton abundance recorded in the present study. Both nutrients are beneficial for algae productivity. The low level of phosphate - phosphorus was also observed by other investigators [15,19, 20]. In both studies, the phosphate - phosphorus values recorded were lower than the WHO standard of $5 \mathrm{mg} / \mathrm{L}$.

\section{CONCLUSION}

In this study, all the physicochemical parameters were determined to be within the permissible level as recommended by FEPA and WHO except DO and BOD were below the permissible levels. Water hardness was above permissible level in some months. Marked monthly and seasonal variations were recorded for temperature, $\mathrm{pH}$, TDS, EC, DO, BOD, water hardness, nitrate-nitrogen and phosphate-phosphorus.

\section{REFERENCES}

1. Samuel PO, Adakole JA, Suleiman B. (2015). Temporal and Spatial Physico-Chemical Parameters of River Galma, Zaria, Kaduna State, Nigeria. Resources and Environment, 5(4):110-123.

2. Komala HP, Nanjundaswamy L, Devi PAG. (2013). An Assessment of Plankton Diversity and abundance of Arkavathi River with Reference to Pollution. Advances in Applied Science Research, 4(2):320-324.

3. Terrumun KK, Oliver TI. (2015). Assessment of the Impact of Abbatoir Effluent on the Water Quality of River Kaduna, Nigeria. World Journal of Environmental Engineering, 3(3):87-94.

4. Emigilati MA, Ishaku I, Usman Y B, Kuta IG, Dangana K. (2015).Assessment of Effluent Discharge From textile Industries in Selected Villages in kaduna State, Nigeria.African Journal of Environmental Science and Technology, 9(5):385-389.

5. Singh Y, Ramteke PW, Shashwat M, Pradeep KS.( 2013).Physico-chemical analysis of Yamuna river water. International Journal of Research in Environmental Science and technology, 3(2):58-60.

6. Ubwa ST, Atoo GH, Offem J, Abah JO, Asemave K. (2013). An assessment of surface water pollution status around Gbokoabbatoir. African Journal of Pure and Applied Chemistry, 7(3):131-138.

7. Ibrahim A. Studies on the Physico-chemical Parameters and Plankton Composition of Ajiwa Reservoir Katsina State, Nigeria. Unpublished M.Sc Thesis, Ahmadu Bello University Zaria, Nigeria, 2014.

8. Dadi-Mahmud NJ, Oniye SJ, Auta J, Kumar N. (2012).Some Physiochemical Parameters of Makera Drain, Kaduna, Nigeria.Indian Journal of Science, 2(1):1-8.

9. Abubakar H. (2015). Assessment of Physiochemical Parameters along Selected Locations of River Kaduna, Kaduna State, Nigeria. Journal of Academic Research, 1(1):11-16.

10. NSDWQ. Nigerian Standard for Drinking Water Quality.Nigerian Industrial Standards (NIS). 2007; p554, standard organization of Nigeria, p30.

11. WHO. Guidelines for drinking water quality. World Health Organisation, Geneva, Netherlands. 2006; 1:491-492. 
12. Edward JB, Ogwumba AAA. (2006).Physiochemical parameters and Plankton Community of Egbe Reservoir Ekiti State Nigeria.Research Journal of Biological Sciences, 5(5):256-367.

13. A.P.H.A. Standard Methods for Examination of Water and Waste Waters. American Public health Association. 1999, New York, USA.

14. Hassan S, Babatunde MM. (2015). Determination of Some Physico-chemical Parameters of Adeyemo Stream, a tributary to River Kaduna, Nigeria. International Journal of Advanced Scientific and Technical Research,5(4):ISSN 2249-9954 (Available at www.rspublications.com/ijst/index.html).

15. Habibat A. Determination of Water Pollution using Oxidative Stress Biomarkers in GlariasGrapienus at Tatsawarki Stream, Kano. Unpublished M.ScThesis.Ahmadu Bello University Zaria, 2016.

16. FEPA. National guidelines and standard for water quality in Nigeria. 1999, Lagos, Nigeria, p114.

17. Addo MA, Darko EO, Gordon C, Nyarko BJB. (2013). Water quality analysis and human health risk assessment of ground water from open wells in the vicinity of a cement factory at Akporkloe, southeastern Ghana. E-Journal of Science and Technology,8(4):15-30.

18. Mahre MY, Akan JC, Moses EA, Ogbubuaja VO. (2007). Pollution Indicators in River Kaduna, Kaduna State Nigeria. Trends in Applied Science Research, 2(4):304-311.

19. Olele NF, Ekelemu JK. (2008). Physiochemical and Periphyton / Phytoplankton study of Onah Lake, Asaba Nigeria. African Journal of General Agriculture, 2(3):183-193.

20. Fadimatu M, Auta J, Sa'idu A. (2019). Phytoplankton Population of River Kaduna, Kaduna State, Nigeria. International Journal of Recent Academic Research,1(7):333-335. 